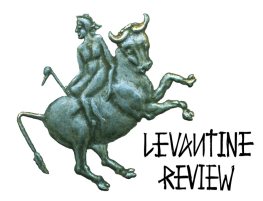

\title{
THE SPRING OF THE NETWORKED NATIONS: SOCIAL MEDIA AND THE ARAB SPRING
}

\author{
Harel Chorev*
}

\begin{abstract}
This essay argues that social media played an important role in the Arab Spring and contributed to a change in the political culture of some of those countries that have gone through regime-change through 2011-2012. The article further posits that the contribution of social media was mainly instrumental, not causal, and that the main reasons behind the Arab Spring were problems generated by regional, local and global trends, affecting each country differently.
\end{abstract}

In April 2009, Moldavian protestors who doubted the results of the parliamentary elections forced the government to recount the votes. ${ }^{1}$ The social media that these protestors made use of, in order to promote their claims, generated a vibrant discourse about the importance of this media as a political tool. The Arab Spring events gave this debate a major push forward. While some analysts argue that social media are having a radical effect on political arenas, ${ }^{2}$ other critics are skeptical. The purpose of this article is to analyze social media as a tool for political change in the Middle East, from its earliest significant use in 2008 through the events commonly referred to as the Arab Spring. Based on qualitative and empirical sources, I evaluate the advantages of social media-based protest networks, and also some of their inherent weaknesses. The changes that social media caused in the traditional patterns of regime-change in the Middle East are noted too; inter-alia, via a brief comparison between the structural characteristics of social media-based protest networks and those of the mosque network that played a role in the Iranian's Islamic revolution of 1978-9. Thereafter, strategies available to regimes in the region for coping with the challenge of social media are discussed, and current trends are used to evaluate the phenomena's long-term influence on the political culture of some of the region's countries.

The main argument of this article is that social media played a critically important role in the Arab Spring and contributed not only to regime transformation, but also to a change in the political culture of some post-revolutionary countries.

Nevertheless, this claim requires two prior clarifications. First, the contribution of social media is mainly instrumental, that is to say, it is not a cause of the uprisings.

\footnotetext{
${ }^{1}$ Anne Applebaum, “In Moldova, the Twitter Revolution That Wasn't”, Washington Post, 21 April 2009.

${ }^{2}$ Clay Shirky, “The Political Power of Social Media”, Foreign Affairs, (January/ February 2011).
} 


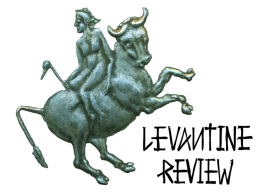

The reasons behind the Arab Spring are problems caused by regional, local and global trends, such as accelerated demographic growth and job markets that cannot absorb millions of educated people. This compounds the fundamental social, economic and political problems in each country, as well as global issues such as the rising prices of essential goods. ${ }^{3}$ Second, the weight and patterns of social media platforms used, differ from one country to another.

In the first decade of the Twenty-First century, the number of people using the Internet increased in the Middle East (1825\%) and Africa (2357\%) more than anywhere else in the world. ${ }^{4}$ Some of this rapid development was the result of the relatively liberal policies adopted by countries such as Egypt, Tunisia and even Syria in recent years. In 2010, for example, the Egyptian government announced that it would invest one billion dollars in improving the country's Internet infrastructure. This was followed by other moves, including reduction in Internet tariffs. ${ }^{5}$ However, despite the fast growth and relative openness of some regimes, the Internet content in Arabic - that is to say in Modern Standard Arabic - Is still poorly developed. In 2010, Modern Standard Arabic content accounted for less than one percent of all Internet content, even though users of Arabic-defined dialects - presumed to be literate in Modern Standard Arabic - constitute approximately five percent of the world's total population. ${ }^{6}$ The low level of development has consequences for many social, political and economic realms. For example, in 2009 the total Internet advertising budget in the Arabic-speaking world was approximately ninety million dollars, whereas it exceeded 5.3 billion dollars in Great Britain alone. However, the situation is not static; the incremental steps taken by both Arab governments and giant corporations like Microsoft and Google that are increasing their involvement in the Arab market, are evidence that the Arabic Internet (in Modern Standard Arabic) is expected to grow quickly in coming years. ${ }^{7}$

Since the Internet revolution began, it has gone through a number of quantum leaps. The initial ordinary Internet sites, which supplied unidirectional information, were soon joined by an ever-increasing number of social media sites, that is to say platforms that allowed for multilateral dialogue. The earliest form of social media was the blog. In 2007, the number of Modern Standard Arabic blogs approached

\footnotetext{
${ }^{3}$ Yitzhak Gal, "Jordan: Economic Challenges and Strategic Ramifications", Iqtisadi, Vol. 1, No. 4 (July 2011), pp. 9-18; Paul Rivlin, "The Politics and Economics of the Arab Spring", Iqtisadi, Vol. 1, No. 5 (September 2011), pp. 8-13.

${ }^{4}$ www. internetworlstats. com/stats. html; www. internetworldstats. com/stats5. htm\#me; \#africa

${ }^{5}$ Alastair Sharp, "The further integration of Arabic language capabilities in internet and other technological architecture will grant millions access to the digital world, Microsoft and Google executives said", Rueters, 24 April 2010: www. reuters. com/article/2010/04/24/us-mideast-internetidUSTRE63N0V120100424?pageNumber2= ${ }^{6}$ Ibid. ${ }^{7}$ Ibid.
} 


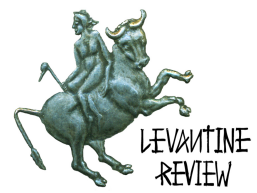

40,000 , but as impressive as this number might be, it was a miniscule percentage ( 0.11 percent) of the approximately 37 million online blogs at the time. ${ }^{8}$ Another quantum leap occurred with the development of social network sites (SNS) in the late 1990s. Most of the first SNS were based on national, professional or other niches ${ }^{9}$ that limited a priori their potential growth. However, in the last five years, there has been another major leap with the appearance of global SNS, such as Facebook (founded in 2004), YouTube (2005), and Twitter (2006). These SNS do not restrict membership based on specific criteria; they even encourage mass enrollment by translating their sites into dozens of languages. In February 2012, Twitter had more than 200 million subscribers, and Facebook had more than 800 million subscribers. The spread of social media did not bypass the Middle East, however (see table 1) its utilization was not necessarily proportionate in every country.

\begin{tabular}{|c|c|c|c|c|c|c|}
\hline Country & $\begin{array}{l}\text { Population } \\
\text { January } 2012\end{array}$ & $\begin{array}{l}\text { Users, in } \\
\text { December } 2000\end{array}$ & $\begin{array}{l}\text { Internet Usage, } \\
\text { January } 2012\end{array}$ & $\begin{array}{l}\text { Internet } \\
\text { Penetration }\end{array}$ & $\begin{array}{l}\text { Facebook } \\
\text { Subscribers }\end{array}$ & $\begin{array}{l}\text { Facebook } \\
\text { Penetration }\end{array}$ \\
\hline Bahrain & $1,214,705$ & 40,000 & 694,009 & $57.1 \%$ & 316,340 & $26 \%$ \\
\hline Egypt & $82,079,636$ & 450,000 & $21,691,776$ & $26.4 \%$ & $9,391,580$ & $11.4 \%$ \\
\hline Iran & $77,891,220$ & 250,000 & $36,500,000$ & $46.9 \%$ & $\mathrm{n} / \mathrm{a}$ & $\mathrm{n} / \mathrm{a}$ \\
\hline Iraq & $30,399,572$ & 12,500 & $1,303,760$ & 4. $3 \%$ & $1,303,760$ & 4. $2 \%$ \\
\hline Israel & $7,473,052$ & $1,270,000$ & $5,263,146$ & $70.4 \%$ & $3,460,000$ & $46.3 \%$ \\
\hline Jordan & $6,508,271$ & 127,300 & $1,987,400$ & $30.5 \%$ & $1,987,400$ & $30.5 \%$ \\
\hline Kuwait & $2,595,628$ & 150,000 & $1,100,000$ & $42.4 \%$ & 880,720 & 33. $9 \%$ \\
\hline Lebanon & $4,143,101$ & 300,000 & $1,367,220$ & $33.0 \%$ & $1,367,220$ & $33 \%$ \\
\hline Libya & $6,597,960$ & 10,000 & 391,880 & $5.9 \%$ & 391,880 & $5.9 \%$ \\
\hline Morocco & $31,968,361$ & 100,000 & $15,656,192$ & $49 \%$ & $4,075,500$ & 12. $7 \%$ \\
\hline Oman & $3,027,959$ & 90,000 & $1,741,804$ & $57.5 \%$ & 362,280 & $12 \%$ \\
\hline West Bank & $2,568,555$ & 35,000 & $1,512,273$ & $58.9 \%$ & 711,440 & $27.7 \%$ \\
\hline Gaza Strip & $1,657,155$ & $\mathrm{n} / \mathrm{a}$ & $n / a$ & $\mathrm{n} / \mathrm{a}$ & $\mathrm{n} / \mathrm{a}$ & $\mathrm{n} / \mathrm{a}$ \\
\hline Qatar & 848,016 & 30,000 & 563,800 & $66.5 \%$ & 323,280 & $38 \%$ \\
\hline Saudi Arabia & $26,131,703$ & 200,000 & $11,400,000$ & $43.6 \%$ & $4,534,760$ & 17. $3 \%$ \\
\hline Sudan & $45,047,502$ & 30,000 & $4,200,000$ & $9.3 \%$ & $\mathrm{n} / \mathrm{a}$ & $\mathrm{n} / \mathrm{a}$ \\
\hline Syria & $22,517,750$ & 30,000 & $4,469,000$ & $19.8 \%$ & $\mathrm{n} / \mathrm{a}$ & $\mathrm{n} / \mathrm{a}$ \\
\hline Tunisia & $10,629,186$ & 100,000 & $3,856,984$ & $36.3 \%$ & $2,799,260$ & $26.3 \%$ \\
\hline
\end{tabular}

\footnotetext{
${ }^{8}$ Mohamed F. Farahat, "Y do U H8 us? Arab Online Forums Examined”, Arab Insight, Vol. 1, No. 2 (Fall 2007).

${ }^{9}$ Dana M. Boyd and Nicole B. Ellison, "Social Network Sites: Definition, History, and Scholarship", Journal of Computer-Mediated Communication, Vol. 13, Issue 1 (November 2008), pp. 210-218.
} 


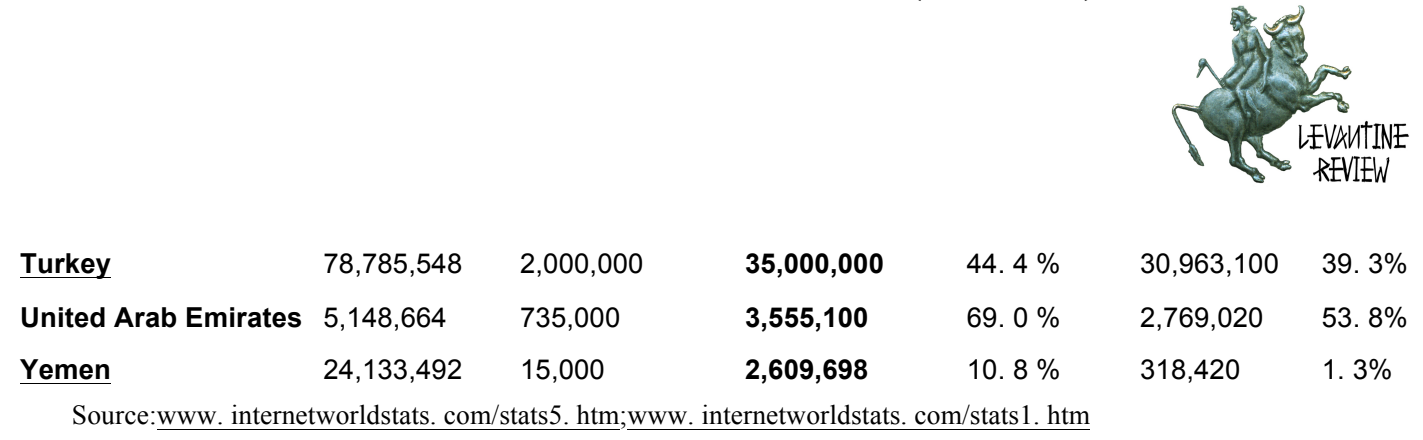

The use of social media for protest was not an innovation of the Arab Spring. In recent years, it has been used around the world by a wide variety of groups, ranging from environmental activists to anarchists. ${ }^{10}$ The earliest significant attempt to use social media for political protest in the Middle East occurred in Egypt in April 2008 at the initiative of a young woman, Isra' 'Abd al-Fattah, who wanted to protest against the steep increases in the price of basic goods and other problems. ${ }^{11}$ Tens of thousands responded to her call on Facebook for demonstration on April 6. ${ }^{12}$ Blogs and SNS were also used in Iran during the mass uprisings that erupted in June 2009. Some observers responded enthusiastically to this initiative, while others were more skeptical. The skeptics claimed that most of the activity on SNS originated with surfers who lived outside of Iran. ${ }^{13}$ This suggested that the discourse in the social media might not have been an accurate reflection of the discourse in situ, and might not have necessarily influenced it. On the one hand, this claim is supported by the fact that the Iranian government removed its blockage of leading SNS, particularly Facebook, only four months (February 2009) before the disturbances erupted. Therefore, it is reasonable to assume that not many Iranians were subscribers in June-July. It should also be noted that Facebook itself delayed having the site translated into Farsi. ${ }^{14}$ Indeed according to data provided by the site Internet World Stats, there were only 250,000 Facebook subscribers in Iran in August 2010,15 a miniscule percentage ( 0.3 percent) of its total population of almost 78 million. This is particularly puzzling when compared to the large number of Internet users in the country (around 33 million at that time.) On the other hand, those who claim that SNS made only a secondary contribution to the protest in Iran, related primarily to Facebook and Twitter, but disregarded other social media vehicles, particularly YouTube. The video showing the last moments in the life of protester Neda AghaSultan, who was apparently shot by Basij militiamen, was rapidly spread around the world using YouTube. The video, which was captured by a simple telephone camera,

\footnotetext{
${ }^{10}$ See for example: Patrick Sawer, "TUC Protest March: Anarchists on the Rampage in London", The Telegraph, 26 March 2011.

${ }^{11}$ Mohammad 'Azam, "Isra' 'Abd al-Fattah: 'Fatat al-Facebook' allatiQadat al-Da'waLiddrab 6 Abril”, AlMasri al-yawm, 9 April 2008.

12 “Al-AmnYuhbatMuzahirawast al-Qahira”, Masrawy website, 6 April 2008: www. masrawy. com/News/Egypt/Politics/2010/april/6/6April. aspx

${ }^{13}$ GolnazEsfandiari, "The Twitter Devolution", Foreign Affairs, 7 June 2010; Malcolm Gladwell, "Small Change", New Yorker, 29 September 2010.

${ }_{15}^{14}$ www. opendemocracy. net/article/email/the-politics-of-facebook-in-iran

${ }^{15}$ www. internetworldstats. com/facebook. htm (Accessed on April 2011).
} 


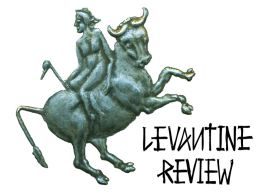

made a profound impression on international public opinion, thereby serving the cause of the Green Movement protests. ${ }^{16}$ Another important social media vehicle in 2009 Iran was the highly developed blogosphere, which contributed to the discourse and organization around the Green Movement protest. ${ }^{17}$

The low percentage of Facebook users in Iran in August 2010 is particularly conspicuous in light of the relatively high percentages in other Middle Eastern and North African countries. In August 2010, there were 1.7 million Facebook users in Tunisia. In Egypt at the same time there were approximately 4.5 million users. Their numbers continue to grow particularly once the protest began: there were 5.2 million Egyptian subscribers in January-February 2011, 6.6 million in March, 7.3 million in August 2011 and 9.3 million in January 2012.18 There is hardly any doubt that this meteoric increase is, at least in part, a response to the central and symbolic role that social media, particularly SNS, like Twitter and Facebook, played in the revolution.

It was the picture of Mohammed Bouazizi in flames, after he immolated himself as an act of protest against the Tunisian regime, and which went viral on the web, that sparked the protests in Tunisia in December 2010. Other countries in the region soon followed. In Egypt, Wael Ghonim, a senior manager for Google, decided with several colleagues to turn the Facebook page they administrated, "We Are All Khalid Sa'id," into a platform for organizing protests in their country. One of their page's most important contributions was organizing the demonstration that launched the revolution on January 25. A few days before the demonstration, the "Like" counter on the Facebook page showed 350,000 "Likes."19 This was an expression of a large, murky wave of frustration, unanticipated by both the authorities and outside observers alike. Ghonim was arrested by Egyptian security forces on January 27. But the ten days that he spent in prison did not harm the organization of the protest. His partners, some of whom were operating outside of Egypt's borders, and visitors of the "We Are All Khalid Sa'id" page, continued to use the site to inform each other of planned protests and encourage demonstrators to stand strong until the regime fell. The page continued adding tens of thousands of fans every day until, on February 9, two days before Mubarak's resignation, its "Like" counter reached 600,000 (from Egypt and abroad). ${ }^{20}$ With a reasonable degree of certainty, we can

\footnotetext{
${ }^{16}$ www. youtube. com/watch?v=Yi21hNoEkaE

${ }^{17}$ Liora Hendelman-Baavur, "Promises and Perils of Weblogistan: Online Personal Journals and the Islamic Republic of Iran", Middle East Review of International Affairs, Vol. 11, No. 2 (June 2007), pp. 7793; http://articles. cnn. com/2009-06-16/tech/iran. twitter. facebook 1 social-networking-sites-iranianssocial-media? s=PM:TECH

${ }^{18} \mathrm{http}$ ://interactiveme. com/index. php/2011/04/egypt-is-the-22nd-biggest-country-on-facebook/

19 Mike Giglio, “The Facebook Freedom Fighter”, Newsweek, 13 February 2011.

${ }^{20}$ www. facebook. com/ElShaheeed (Accessed on 9 February 2011).
} 


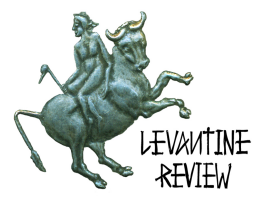

assume that the page's exposure was even greater, because messages originating there were transferred to more traditional "grapevines."

\section{The SNS Revolution}

The central role of media in promoting revolutions and political agendas is not a new phenomenon. This was evident in Martin Luther's ninety-five printed theses in the early Sixteenth century, ${ }^{21}$ and in more recent times in Ayatollah Khomeini's cassette tapes of the 1970s. ${ }^{22}$ In the contemporary Middle Eastern context, we cannot ignore the significant role played by satellite television networks, especially Al-Jazeera, which has been broadcasting to the masses over the heads of the regimes since 1996. However, satellite networks and global communications, as a whole, have experienced massive changes in recent years, as a direct consequence of the growth of social media. The news corporations, for example, have radically changed their operational structure away from more traditional forms. Instead of relying exclusively on professional journalists and photographers, newsrooms are increasingly using materials created by a variety of amateur sources, which arrive directly from the scene of events. This requires making substantive changes in the structure of the editing and fact-checking of materials, ${ }^{23}$ but it also provides them with an unprecedented opportunity to be everywhere, and get there quickly. Furthermore, the rise of social media forced the news corporations to change their traditional business model, and expand the platforms they use to provide news free of charge. According to some observers, these developments have made the news business more participatory, diverse and partisan; a development that in many ways has returned journalism to its $19^{\text {th }}$ century form: chaotic, free and highly political. ${ }^{24}$

The changes in the news business are just one example of the multidisciplinary, global impact of social media. It has also caused deep changes in economic fields such as marketing and the free labor market, as well as in other realms. In other words, the role played by social media in the Arab Spring is a conspicuous example

\footnotetext{
${ }^{21}$ Mark U. Edwards Jr. ,Printing Propaganda and Martin Luther (Minneapolis: Fortress Press, 1994).

${ }^{22}$ Daniel E. Harmon, Ayatollah Ruhollah Khomeini (Chicago: Chelsea House Publishers, 2005), pp. 39, 42; Charles Hirschkind, The Ethical Soundscape: Cassettes Sermons and Islamic counterpublics (New York: Columbia University Press, 2006).

${ }^{23}$ See Washington Post's ad seeking for a social media editor: www. linkedin. com/news?actionBar $=\&$ articleID $=706461241 \&$ ids $=0$ PdPAQcP8Sc3sIdz4Mcj4Ndj0Tb3oQej0TdPsMdOM Nd38NdzgSc3sIejoNcPATdj0T\&aag=true\&freq=weekly\&trk=eml-tod-b-ttle-68 (Accessed on 23 August 2011).

24،"Bulletins from the Future", The Economist, 9 July 2011, pp. 3-5; "The People Formerly Known as the Audience", ibid, pp. 9-12.
} 


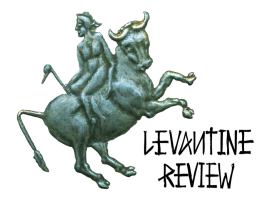

of its political influence, but it is only one aspect of a much larger and allencompassing phenomenon.

Social media, as it appeared during the Arab Spring, offers six advantages for political protests. The first and most important advantage is not, as many observers have claimed, ${ }^{25}$ the ability to coordinate the masses. Although this virtue is indeed important, the most crucial aspect is the ability of SNS to provide a platform for establishing heterogeneous coalitions that cut across social and political lines. This heterogeneity is the outcome of the ability of supporters to join the protest through the SNS without any limitations imposed by other social or political traits. Therefore, SNS can serve as a platform for a coalition built around a unifying goal, like toppling the regime, even if its members are not unified on any other issue.

Some SNS were indeed identified with specific groups of users. For example, mapping the fans of "We Are All Khalid Sa'id" showed that most of them lived in Alexandria and Cairo, mostly in the Giza quarter and adjacent areas. ${ }^{26}$ Freelon's empirical mapping of Twitters' "tweets" showed that a significant proportion of the participants in the dialogue concerning events of the Arab Spring were not necessarily physically present in the countries where the uprisings took place. ${ }^{27}$ However, heterogeneity is not necessarily expressed in the geographical, social and political character of any particular site, but rather in the interaction and cooperation between all of the various social media' platforms that were active during the events. My assumption on this point was reinforced by results of the elections for the Egyptian parliament held in late 2011. The sweeping victory of the Islamic movements surprised many observers who assumed that the Egyptian revolution was led by educated urban and liberal young people. The massive media coverage of the role SNS played, undoubtedly contributed to this inaccurate perception, as if innovative media is not the kind of tool that can be used by more conservative elements who "stole," as it were, victory from the hands of young liberals. That assumption is precisely the root of the problem, since no significant political force has remained outside the cybernetic arena, which was characterized by social-political heterogeneity even before the outbreak of the Arab Spring. Empirical evidence for this can be found in studies conducted by the Berkman Center at Harvard in 2009, which showed that a wide variety of social and political forces, including representatives from the major Islamist movements, were active in

\footnotetext{
${ }^{25}$ A conspicuous advocate of this claim is Clay Shirky, see: Clay Shirky, "The political Power of Social Media" Foreign Affairs, Vol. 90, No. 1, (January/ February 2011).

${ }^{26}$ AnverEmon, Ellen Lust and Audrey Macklin, "We are all Khaled Said", Boston Review, 3 November 2011: http://www. bostonreview.net/BR36. 6/khaled said facebook egypt revolution.php

${ }^{27}$ DeenFreelon, “The MENA Protest on Twitter: Some Empirical Data”,dfreelon.Orgwebsite, 19 May 2011:http://dfreelon. org/2011/05/19/the-mena-protests-on-twitter-some-empirical-data/
} 


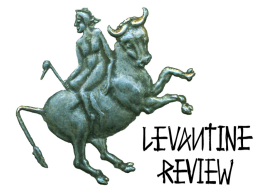

the blogosphere of the Middle East generally, and of Egypt particularly. ${ }^{28}$ This is the heterogeneity that made it possible to establish the Cyber Coalition that called for toppling Mubarak's rule during the Egyptian revolution.

The second advantage of SNS-based protest networks is their large size, which is a direct result of their character as a heterogeneous social-political platform. Beyond the issue of heterogeneity within the country, the SNS-based protest network is not limited by physical or national borders. Therefore, it can spread beyond borders to obtain real economic, moral and political assistance from actors in other countries. There is considerable empirical evidence ${ }^{29}$ of the intensive involvement of external actors, at least since the events of June 2009 in Iran. Some claim to see this as proof of the weakness of the social media phenomenon in those countries, ${ }^{30}$ however, these actors are an integral part of the protest networks, and the operational, economic, moral and political support that they provide on the ground is real and absolutely necessary. One such person was Nadin Wahab. From her home in California, she played a major role in running the page "We Are All Khalid Sa'id" after Ghonim's arrest, and the ability of her other colleagues in Egypt to administrate the page was limited because of their fear of the authorities and also because of Facebook's policy, which prohibits the use of false identities. ${ }^{31}$ Other external actors established the site "How to help Egypt," in order to provide Egyptians with toll-free numbers so as to continue connecting to the Internet via foreign providers, thereby bypassing the ISP blocking imposed by the government on January $27 .{ }^{32}$ Additional external actors, some from unexpected places, served the protest movements with clips that bolstered the insurgents' morale. These clips were viewed several million times and had a great impact on world opinion. This phenomenon was particularly evident in Libya and Syria, where video sites, led by YouTube, played a more important role than other platforms of social media (for more on these differences, see below). ${ }^{33}$

Another advantage of social media is its ability to surprise the regime with the broad aforementioned coalition, as well as with other collective actions that can be organized on very short notice. This surprise is sometimes the result of a

\footnotetext{
${ }^{28} \mathrm{http}$ ://globalvoicesonline. org/2009/06/11/mapping-iran\%E2\%80\%99s-blogosphere-on-election-eve/; http://blogs. law. harvard. edu/idblog/2009/06/16/internet-and-democracy-releases-report-of-arabicblogosphere/

${ }^{29}$ See for example: Freelon, "The MENA Protest".

${ }^{30}$ Esfandiari, "The Twitter Devolution".

${ }^{31}$ Emon, Lust and Macklin, "We are all Khaled Said".

${ }^{32}$ Bianca Bosker, "How to Help Egypt Get Online", Huffingtonpost website, 19 January 2011: www. huffingtonpost. com/2011/01/29/how-to-help-egypt-get-online n 815880.

html\#s232601\&title=Anonymous

${ }^{33}$ Isabel Kershner, "Qaddafi YouTube Spoof by Israeli gets Arab Fans", New York Times, 27 February 2011.
} 


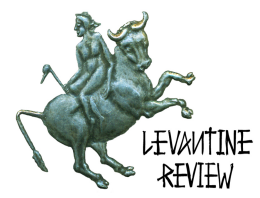

spontaneous, mass organization, like the one that followed the distribution of the picture of Mohammed Bouazizi; sometimes it is the result of an initiative taken by a small number of people, as the stories of Isra' 'Abd al-Fattah and Wael Ghonim show. The mechanism behind this rapid gathering is connected to the psychological impact of the social media outlets, which provide the individual at home or at an Internet café with confirmation that there are many others who share his or her views and anger. Therefore, if $\mathrm{s}$ /he were just to join the wave of protests, the chance that their goals will be achieved increases. This important process of internalization, multiplied by several hundred thousand users, can be the final factor that flips the switch to release the masses into the streets. Prior to the 2011 events, many regimes in the Middle East did not pay proper attention to social media, which made it difficult -although not impossible - to identify the sources of protest in advance. This explains why some of the uprisings, particularly in Tunisia and Egypt, took not only the regimes, but also external observers, by surprise. Apparently this lesson was not always learned quickly. Israel, for example, was caught by surprise by the Nakba Day events on May 15, 2011 when thousands of demonstrators, mobilized via Facebook and other SNS, attempted, sometimes successfully, to infiltrate its borders with Syria and Lebanon. Another example took place on September 9, 2011, when Egyptian demonstrators attacked the Israeli embassy following a short-notice call on Twitter. ${ }^{34}$

Three additional advantages have been discussed at some length in the current discourse. One of them is the ability of social media to defuse government monopoly on information. Because they do not need expensive broadcast equipment, SNS and blogs are easily accessible and make it possible to present alternative information and inspiring stories of protest that bypass the official narrative. This is especially true when the authorities are not organized to monitor or limit the use of social media and other Internet tools that neutralize their control of traditional media outlets.

A widely discussed advantage of social media is its ability to coordinate the masses. Instant messages can be sent to a very large number of users spread out over a large area. Smartphones facilitate active pushing of SNS messages, which further multiplies their advantages as a tool for multilateral coordination of protesting crowds. This makes it possible to mobilize demonstrators while receiving feedback from the field, which facilitates continuing the protest even in the face of the regime's suppressive operations. It follows that a high level of organization is not essential. Rather, the ability to create "organized chaos" is sufficient to maintain the momentum of demonstrations that might exhaust the authorities.

34،“AinTaht‘Ain”, Al-Masri al-yawm, 10 September 2011. 


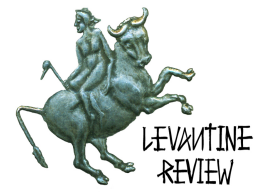

The last advantage of SNS is that they are decentralized systems, in which information is disseminated from multiple locations. This decentralization provides those systems with a high level of redundancy that allows them to continue circulating information even if a large number of human or technological centers cease to function. The fact that the page established by Ghonim continued operating after his arrest is a clear example of this advantage. Moreover, that page was not the only force in the protest using a social media platform. There were other Facebook pages, "tweets" and blogs used by central activists and journalists, who shared events with surfers from all over the world. Even if some of these sources were blocked, it would not have been possible to stop the flow of information created by other sources.

The aforementioned characteristics represent a fundamental development in the traditional pattern of uprisings and regime changes in the Middle East, but also in the political cultures of the post-revolutionary countries. A conventional "revolutionary" pattern in the Middle East had been the take-over of government radio and television stations; usually as a first step in traditional coup d'états. Social media has rendered this step, which was once indispensable for mobilizing the masses and driving them into the streets, functionally worthless.

Another deviation from past Arab norms of "transfers of power" occurred in the traditional characteristic of regime changers. In the past, insurgents who replaced deposed governments, whether the Free Officers in Egypt, or the Ba'ath activists in Iraq and Syria, underwent a long period of incubation, and social and political consolidation, before actually taking the helms of power. The Arab Spring revolutions lacked this type of leadership group. Indeed, a salient characteristic of the uprisings in Tunisia, Egypt, Libya and Syria had been their conspicuous lack of identifiable leadership figures. A few people, such as Ghonim, have become symbols of their respective countries' revolutions. However, Ghonim never claimed any leadership role for himself, and indeed, rejected any such possibility, arguably in an attempt to maintain the popular, non-partisan nature of the revolution. ${ }^{35}$ In other words, Ghonim wished to maintain the revolution's social and political heterogeneity that gave it both its quantitative and moral power. Consequently, more than a few observers predicted, even as events in the Middle East began to unfold, that there was a good chance that Islamic movements would take over government institutions in various countries, primarily because they were the most organized groups in population. This was a prevalent assumption also because Islamists enjoyed a certain level of popular legitimacy due to their record of providing civil assistance to the population, and the fact they were continuously persecuted by the deposed regime.

${ }^{35}$ Giglio, "The Facebook Freedom Fighter". 


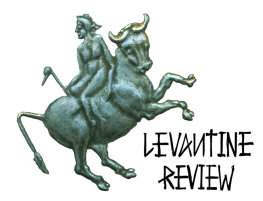

\section{'The Strength of Weak Ties': A Comparative Look at SNS and Conventional Social Networks}

Some critics emphasize the modest penetration of Facebook in some Arab countries, especially Egypt, during the events of early 2011 to back their claim that social media did not play a central part in the events. ${ }^{36}$ Two points to counter this argument should be noted: first, even the modest Facebook penetration to Egypt during the January-February events (6.2 percent) meant that a substantial number of Egyptians, 5.2 million, were subscribers. This figure seems to be more than enough for an avant-garde to lead and support the popular protest in the streets. The administrators of "We Are All Khalid Sa'id" became accustomed to seeing posters and graffiti on the street, using slogans that had been coined and published by them on the page only a few hours earlier. ${ }^{37}$ Facebook, however, was not the only social media vehicle used in Egypt. As in other countries, Twitter, YouTube, blogs and other social media outlets were also used. ${ }^{38}$ Second, messages that were originally disseminated by social media outlets were also spread by word-of-mouth, and can, therefore, be considered part of social media's indirect effects. This process is comparable to the accepted practice in the Middle East during the late nineteenth and early twentieth centuries, when a few people read newspapers aloud for large groups of illiterate listeners who congregated in cafes and other public places. These listeners were an inseparable part of the newspapers' circle of influence. ${ }^{39}$

A prominent critic of the concept that social media can play a significant part of political mobilization is Malcolm Gladwell, the New Yorker commentator. Gladwell contended that activism on SNS does not increase people's motivation when asked to make a genuine effort to bring about revolutionary change. He also claimed that the ability of revolutionary movements to take significant action requires stronger bonds of comradeship than the supposedly weak connections offered by cybernetic networks. ${ }^{40}$ He referred to studies of the Italian Red Brigades, which showed that each member of this terrorist network had a strong, parallel connection with at least one other member of the organization. A similar principle applies to the Mujahedin who fought the Russian army in Afghanistan, and the East German protest

\footnotetext{
${ }^{36}$ See for example: "Social Media and the Wall Street Protest", The Economist, 11 October 2011.

${ }^{37}$ Emon, Lust and Macklin, "We are all Khaled Said".

${ }^{38}$ On Twitter's role see: Freelon, "The MENA Protest”; Blake Hounshell, "The Revolution will be Tweeted", Foreign Policy, (July/August 2011).

${ }^{39}$ Many of those early newspapers used a language that resembled Levantine spoken variants, which allowed for better local comprehension, even when read to the illiterate.

${ }^{40}$ Malcolm Gladwell, "Small Change", The New Yorker, 29 September 2010; Ghanaym al-Tyb, "Egypt's Back Yard”(in Hebrew), Haaretz, 18 April 2011.
} 


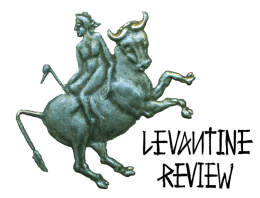

movements that consisted of several hundred clusters of approximately one dozen close friends each. ${ }^{41}$

An essential assumption for understanding the phenomenon of SNS is that the connections created in these networks, as shallow as they seem at first glance, are not necessarily limited to the Internet sphere. It is not rare for conventional systems of relationships to contain overlapping dimensions of family, friendship, workplace, neighborhood, organizational, ceremonial and other relationships. Consequently, they can certainly contain another dimension: a cybernetic connection. This means that there is no contradiction between conventional social networks and "modern" social networks created via SNS. Furthermore, there is nothing to prevent them from integrating into each other, in a manner that reinforces the system of relationships as a whole, on the basis of a simple principle, namely, "the more connections, the more cohesiveness." A representative example of this type of integration is the use that Islamic scholars such as Sheikh Yusuf al-Qaradawi have long made of the Internet in general, and of social media in particular, in order to disseminate their philosophy, answer questions, raise funds, and suchlike. ${ }^{42}$ Clearly, this does not weaken their relationships with their audience; quite the contrary. Used wisely, it can strengthen them. Their messages can travel further; they receive more exposure and have the potential to increase their income, prestige and influence.

Three additional arguments can be made to counter Gladwell's perception of SNS as uni-dimensional networks that lack the bonds of comradeship that, in his view, are essential for significant activism. First, although many of the connections based on social media are indeed characterized by shallowness, there are many others, which are reinforced, as explained above, by parallel ties. These relationships exist within numerous clusters of friends that are active on the SNS. Indeed, their cybernetic gathering represents conventional social groups that exist beyond the Internet sphere. Anyone who joins Facebook, Twitter, LinkedIn and other SNS knows that the most common foundation for creating "friendships" is the new subscriber's e-mail address book, which is used to invite others to join the SNS as well. Needless to say, a verbal recommendation between friends to join the SNS expresses the same thing: cybernetic relationships that reflect existing conventional relationships. As in the example of the Islamic scholars, the added SNS tie contribute to the cohesiveness of the relationships by maintaining contact between people, locating friends with whom the connections have weakened, and so on. Occasionally, the direction is reversed when ties that begin on SNS lead to a conventional relationship.

\footnotetext{
${ }^{41} \mathrm{http} / / /$ socialcapital. wordpress. com/2010/09/29/why-the-revolution-wont-be-tweeted/

${ }^{42}$ www. islamonline. net/servlet/Satellite?pagename=IslamOnline-EnglishAsk Scholar/FatwaE/FatwaE\&cid $=1119503543546$
} 


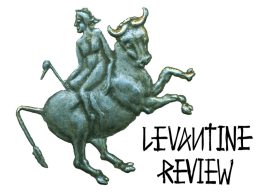

Second, even if we assume that Gladwell is correct and the relationships developed on SNS are weak, there is nothing to prevent broad coalitions from developing around claims with wide public support: whether the issue is Bank of America's high interest rates or the toppling of an unpopular government. Many examples can be drawn from last year alone. Third, even if SNS connections are different from those known to us from other revolutionary movements, the assumption that traditional conditions and patterns have changed profoundly should not be dismissed: Are phenomena like "Facebook depression" 43 and obsessive accumulation of cybernetic "friends" and "Like" comments traditional, or are they new and unprecedented phenomena that indicate that psychological, social, cultural, political and other fields have deeply changed under the impact of the virtual world-hence suggesting that our whole methodological approach be different?

None of the above should be taken to mean that SNS are free of weaknesses. They do have their weaknesses. As shown earlier, they do not create stable leadership that can take the place of an ousted government and complete the revolutionary process. However, it should be emphasized that not every characteristic that is considered shallow is necessarily an expression of weakness. Structural comparison to other protest networks may clarify this point. Scholarly literature customarily attributes an important role in the Iranian Islamic revolution to the mosque network. ${ }^{44}$ The latter was described as a condensed network that had many multi-dimensional connections. Each mosque reflected a cluster of ceremonial, neighborly, familial, ideological, economic, clientelistic and other ties. Yet scholars such as Kurtzman contended that the influence attributed to the mosque networks was exaggerated. He argued that, with the exception of the climactic months of the revolution in late 1978 and early 1979, the mosque network structure was highly problematic: Communications between the mosques was slow and cumbersome; their political connections were frequently weak because many religious leaders feared expressing opposition to the Shah and some of them were not necessarily his opponents. Furthermore, the characteristic pattern of the network's connections was highly divided and decentralized. Therefore, its topology challenged the ability of Khomeini and his loyalists to take control of the mosque network, even after the revolution was completed. 45

As mentioned above, SNS, like the mosque network, consist of clusters of friends who are frequently linked to each other with conventional, multi-dimensional

\footnotetext{
${ }^{43}$ On Facebook Depression see:www. readwriteweb. com/archives/new illness facebook depression. php.

${ }^{44}$ See for example: Mohammad M. Salehi, Insurgency through Culture and Religion: the Islamic Revolution in Iran (New York: Praeger, 1988).

${ }^{45}$ Charles Kurtzman, "The Network Metaphor \& the Mosque Network in Iran, 1978-1979”, in Miriam Cook and Bruce B. Lawrence (eds. ), Muslim Networks: from Hajj to Hip Hop (Chapel Hill and London: the University of North Carolina, 2005), pp. 69-83.
} 


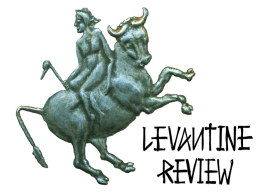

relationships. But even if we assume that the mosque network benefited from the advantage of more varied and deeper relationships, SNS have their own structural advantages; the most conspicuous is the communication they facilitate. The pace and quantity of the messages transmitted via SNS is immeasurably greater than those transmitted via the slow communication ties of the Iranian mosque network. This advantage, which allows for rapid exchange of ideas and influences, makes a direct contribution to the density and cohesiveness of the protest movements they serve. ${ }^{46}$ Another important advantage is the growth potential of SNS; it simply cannot be compared to that of the Iranian mosque network, which was ultimately limited to the approximately 9015 mosques that were operating in the country prior to the revolution. ${ }^{47}$ Unlike the mosque network, an SNS-based protest network is not limited to any single social, religious or political group; nor is it confined by physical or national borders. This allows it to benefit from the support of activists functioning from abroad. From there, as mentioned before, these activists helped the protest network in administrating Facebook pages, raising funds, allocating technological resources, and disseminating the message of the revolution around the world in order to create international public opinion and exert external diplomatic pressure on the regime. ${ }^{48}$

Conversely, the mosque network benefited from a tradition that the SNS-based protest movements lacked. Indeed, the ability of the Iranian authorities, since 1979, to weaken another traditional network that supported the Islamic revolution, the bazaar network, shows that tradition does not necessarily ensure the survival of the network. ${ }^{49}$ However, we can surmise that the ability of such networks to survive is greater than the SNS-based protest networks, whose ability to maintain their cohesiveness seems very doubtful in light of the experience gained in the meantime.

The Arab Spring proved that headless revolutions are indeed possible. However, the lack of a head is very problematic in the long-run. Even if the new leadership is chosen democratically, there is no guarantee that it will be satisfactory to all of the groups in the heterogeneous coalition that worked to remove the previous regime. Naturally, this might have a negative impact on the movement's ability to continue as a single interest group. This leads us to the assessment that groups like the "January $25^{\text {th }}$ Coalition" cannot be expected to continue as a long-term, active force

\footnotetext{
${ }^{46}$ NitinNohria, "Is a Network Perspective a Useful Way of Studying Organizations?" in idem and Robert G. Eccles (eds. ), Networks and Organizations: Structure, Form, and Action (Boston: Harvard Business School, 1992), p. 6.

${ }^{47}$ Kurtzman, "the Mosque Network", p. 71.

${ }^{48}$ On outside help see: www. huffingtonpost. com/2011/01/29/how-to-help-egypt-get-online n 815880 . html\#s232601\&title=Anonymous; See a Libyan ask for help through the SNS: http://forum. xdadevelopers. com/showthread. php?t=981579

${ }^{49}$ ArangKeshavarzian, Bazaar and State in Iran: the Politics of the Tehran Marketplace (Cambridge, UK $\&$ New York: Cambridge University Press, 2007).
} 


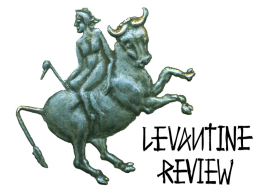

in the political arena, at least not in its original, heterogenic form. However, more important is the heritage that these groups bequeath to whatever government might be established; that is to say the barrier of fear that they broke, and the threat that the masses will gather again to overthrow an undesirable regime.

\section{The Revolution will be Tweeted}

The ability of social media to overcome the centralized power of a nation-state is a challenge faced not only by authoritarian regimes, whether in the Middle East or elsewhere. As French President Nicholas Sarkozy admitted in May 2011, it also deeply concerns Western governments. ${ }^{50}$ The riots that erupted in Britain two months later were organized on Facebook, Twitter, and even via the Blackberry BBM messages service (which is also a social network); they are an outstanding example of what worried Sarkozy. ${ }^{51}$ Indeed, there has been a radical change not only in the public's ability to organize and coordinate, but also in the state's ability to govern, even in the context of democratic regimes.

Nevertheless, it is worthwhile to avoid generalizations and attributing similar power and traits to phenomena as they appear in different countries. This is certainly true in the Middle East, if only because not all countries have a substantial SNS infrastructure (see table 1). Libya, for example, responded to the uprisings in Tunisia and Egypt by temporarily blocking the Internet, 52 although SNS like Facebook and Twitter played a less important role in Libya than in either of Tunisia and Egypt. It is reasonable to assume that this is directly related to the relatively small number of SNS subscribers, as can be seen in the table above which shows a miniscule (0. 8 percent) Facebook penetration in Libya during most of 2011. Apparently, the domino effect of the Tunisian and Egyptian examples, and of course NATO's support of the rebels, were more important in determining the course of events in Libya. Social media is also playing a role in the Syrian uprising. However, its role there is different than it was in Tunisia or Egypt, but it is still significant. In

\footnotetext{
${ }^{50}$ Emma Barnett, "Sarkozy Prioritises Internet Regulation at G8 Summit”, The Telegraph, 24 May 2011.

${ }^{51}$ Mathew Ingram, "Network Effects: Social Media's Role in the London Riots", Bloomberg BusinessWeek website, 8 August 2011: http://www. businessweek. com/technology/network-effects-social-medias-role-inthe-london-riots-08082011. html;"London riots: social media bosses questioned - video", The Guardian website, 16 September 2011: www. guardian. co. uk/uk/video/2011/sep/16/uk-social-media-chiefsquestioned-video

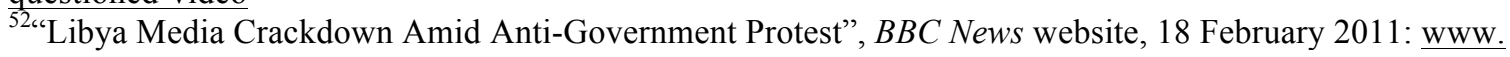
bbc. co. uk/news/world-middle-east-12512202; "Updated: As Arabia Protests, Libya Blocks Internet Access", Neosmart website, 18 February 2011:http://neosmart. net/blog/2011/as-arabia-protests-libya-blocks-internet-access/; "Libya Follows Egypt's Lead: Starts Shutting off Internet Service”, Technochurch website, 18 February 2011; http:/techcrunch. com/2011/02/18/reports-libya-follows-egypts-lead-starts-shutting-off-internetservices/
} 


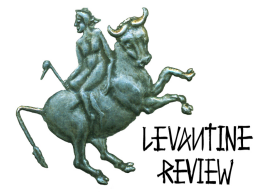

August 2010, the number of Facebook subscribers in Syria was significantly lower than in Egypt or Tunisia (30,000 as compared to 4,595,160 and 1,671,840 respectively). “The Syrian Revolution” Facebook page, which was opened in January 2011 for the purpose of encouraging political changes in Syria, did not receive a particularly impressive response in the first months of its existence. Two months after it went online, and despite the fact that protests had already swept through Syrian cities, the page had fewer than 50,000 "Likes"53; not many in comparison to the several hundred thousand responses on the Egyptian "We Are All Khalid Sa'id" page. Most of the feedback on the Syrian page came after the protests had already begun, and therefore should be interpreted as a response to events, rather than a catalyst for them. The contribution of Facebook and Twitter to the Syrian uprising was, therefore, not particularly significant. However, YouTube played and still plays a major role because it provided Syrian protesters with an outlet where they could upload, almost in real time, videos of events on the ground. Therefore, as in Iran 2009 , the video-sharing site became the principal tool to transmit to the world images of the bloody confrontation with the security forces; scenes that contrasted sharply with the reports broadcast by the official Syrian outlets. ${ }^{54}$

This reality exposes the radical change in conditions, especially from the perspective of the Syrian regime. Comparison to the events in the city of Hama in 1982, when the army killed tens of thousands of the city residents, is inevitable. Those killings came to the world's attention only after a delay, and to this day, the number of fatalities remains vague. It now seems that this type of isolation has irrevocably passed from the world, because of the development of the media in general and social media in particular. The events of the Arab Spring, as well as other protests and events in democratic countries, such as those of Great Britain during the summer of 2011, prove that SNS-organized protests are able to grow quickly without perceptible advance warning. Most authoritarian regimes in the Middle East are not currently capable of mounting a sophisticated response to these challenges although they present a clear threat to the regimes' ability to maintain their centralized power. Therefore, it would seem that they have two possible options for responding.

The first option is to adopt a draconian policy towards the Internet as a whole and particularly against social media. Nepal and Myanmar, for example, blocked Internet access in 2005 and 2007, respectively, in response to internal crises. Approximately forty other countries regularly take preventative measures including blocking

\footnotetext{
${ }^{53}$ www. facebook. com/Syrian. Revolution (Accessed on 15 March 2011).

54"Syria Follows Egypt in Blocking the Internet", YaLiban website, 29 January 2011: www. yalibnan. com/2011/01/29/syria-follows-egypt-in-blocking-the-internet-report/; "Syria Internet Disrupted As Egypt Blackout Catches On In Middle East”, Huffingtonpost website, 28 January 2011: www. huffingtonpost. com/2011/01/28/syria-internet-down n 815337. html
} 


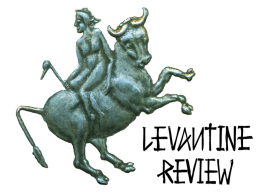

access to specific websites and search words. ${ }^{55}$ In 2008, Turkey blocked access to YouTube because of videos it considered insulting to Atatürk. In June 2010, Turkey also blocked the sites of various services offered by Google. However, the most massive blocking of access to the Internet was imposed by Egypt on January 27, 2011 when the Mubarak government ordered Internet service suppliers to halt transmissions on the network. Access was permitted to only a few sites, such as those belonging to the stock exchange and a few government ministries. ${ }^{56}$

The Egyptian case clarified the weaknesses inherent in adopting draconian methods limiting free Internet activity. First, the blockage led to virulent public and international outcry because of the impairment to freedom of expression and freedom of communication. Second, reports from Egypt claimed that blocking Internet not only did not calm the atmosphere, but rather brought protesters out into the streets. Third, in Egypt like many other countries, the Internet is a central component of the information infrastructure on which the country's critical economic and governmental functions depend for both domestic and international operations. Hence, blocking the Internet can cause the state massive damage. ${ }^{57}$ Fourth, halting the activity of Egyptian Internet providers did not necessarily stop protesters from accessing the Internet. Internet can also be accessed via dial-up connections to overseas providers, using ordinary telephone lines. As mention above, detours of this type were indeed used during the Egyptian revolution, thanks to the assistance that the SNS were able to recruit among foreign supporters, including toll-free numbers to access the Internet via overseas suppliers. ${ }^{58}$ Another example is the assistance provided overnight by Google and Twitter, who developed software for transmitting tweets generated by simple voice messages. This bypass could be blocked off only by disconnecting the entire telephone network; a step whose severe implications on the economy and state's ability to function normally, render it highly unlikely. In conclusion, draconian approaches to the Internet cannot be maintained for a long time without causing damage to other critical systems, and without the invention of bypass solutions.

Considering the problematic option of blocking the Internet, regimes do have another choice: "If you can't beat them, join them." This policy was quickly adopted by the Egyptian government after the resignation of Mubarak. Senior officials, including the chairman of the Supreme Council of the Armed Forces and acting head of state, Field Marshal Mohammed Hussein Tantawi, created Facebook pages for

\footnotetext{
${ }^{55}$ Matt Richtel, "Egypt Cuts Off Most Internet and Cell Service”, New York Times, 28 January 2011.

${ }^{56}$ Noam Cohen, "Egyptians were Unplugged and Uncowed”New York Times, 20 January 2011.

${ }^{57}$ Christopher Rhoads, "Syria's Internet Blockage Brings Risk of Backfire", Wall Street Journal, 3 June 2011.

${ }^{58}$ Bianca Bosker, "How to Help Egypt Get Online”, Huffington Postwebsite, 19 January 2011: www. huffingtonpost. com/2011/01/29/how-to-help-egypt-get-online n 815880.

html\#s232601\&title=Anonymous
} 


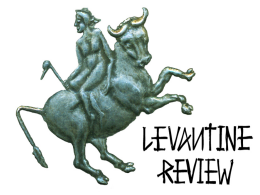

themselves. An even more important advantage of avoiding any blocking of the Internet and the social media in particular, is the understanding that it is a valuable open-source of information, and when allowed to operate uninterruptedly, it can be used for intelligence purposes. In that case, SNS could have a boomerang effect against protest groups. It should be emphasized that this approach is not restricted to authoritarian regimes but rather used by most Western police forces and intelligence agencies. For example, one source claimed during the riots of Summer 2011 in Britain that the police disseminated disinformation using SNS in order to confuse and disperse rioters. ${ }^{59}$ Furthermore, even commercial enterprises that monitor the Internet are capable of producing in-depth analyses of the information they find. Iran was one of the first Middle Eastern countries to establish a sophisticated Internet monitoring system. Approximately one year after the system, manufactured by Nokia-Siemens, was completed in 2008, it was used against the Green Movement protests in June 2009.60 According to some reports, Iran has also helped its ally Syria with similar services during the ongoing turmoil there. ${ }^{61}$

It is doubtful that most Middle Eastern countries are currently equipped with technological and analytical means similar to those used by the Iranians. However, it should also be noted that even these measures do not always allow hermetic control of the social media sphere; increasingly, surfers have more means available to them for bypassing limitations imposed on the Internet, including measures for disguising their identity. ${ }^{62}$ In conclusion, the two aforementioned possible forms of response do not offer regimes in the region a completely effective response to the challenges posed by social media. Temporary, focused responses are indeed possible. However, in the long-term it does seem that protest movements will be able to use technological solutions, which are constantly being developed, in order to bypass barriers erected by regimes.

\section{Conclusion}

During the first decade of the twenty first century, the Internet's penetration into the Middle East and North Africa increased more than in any other region in the world. This process added tens of millions of users who joined the world-wide trend and subscribed to global SNS and other social media vehicles. The demonstrations in

\footnotetext{
${ }^{59}$ Josh Halliday, "London Riots: How BlackBerry Messenger Played a Key Role”, The Guardian, 8 August 2011.

${ }^{60}$ Eli Lake, "Fed Contractor, Cell Phone Maker Sold Spy System to Iran”, Washington Times, 13 April, 20 June 2009; Christopher Roads and Loretta Chao, "Iran's Web Spying Aided By Western Technology", Wall Street Journal, 22 June 2009.

${ }^{61}$ PutuKarya, "Iran Allegedly Helps Syria to Silence the Protesters", Allvoices website, 28 May 2011:www. allvoices. com/contributed-news/9236805-iran-allegedly-helps-syria-to-silence-the-protesters

${ }^{62}$ See for example:www. torproject. org; www. hidemyass. com
} 


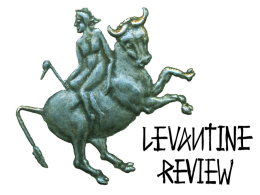

Egypt in April 2008 and Iran in June 2009 were initial attempts to use social media as a tool for political mobilization. Although social media's influence on these two events is debatable, its contribution to those in 2011 is more conspicuous, tangible and symbolic. During the Arab Spring, social media appeared as a groundbreaking development that made a major contribution to the protest movements, especially in Tunisia and Egypt, but also in Syria and Libya, though by different vehicles. Interestingly, there was a dramatic leap in the number of Facebook user in Libya, occurring in the four months after Qaddafi's death on August 20, 2011. During that month there were only approximately 52,860 Libyans using Facebook, but that number increased almost eight-fold to 391,880 in January 2012.

The Arab Spring events gave expression to what seems to be the greatest virtue of social media: its ability to create a platform for the rapid formation of huge protest coalitions. Therefore, social media was able to help these coalitions rise above political and social differences, and created a cybernetic ecology of civil society. The size of these heterogeneous coalitions and the speed at which they developed came as a surprise to both the regimes themselves and external observers who had great difficulty predicting the looming political earthquake in the Middle East. The Arab Spring was also a successful test-case of social media's ability to serve as a means for coordinating the masses and neutralizing the governments' narrative.

This, therefore, begs a critical question: will authoritarian regimes in the Arab world be able to maintain their current format when faced with an increasingly large public that is taking significant portion of their centralized power. Democratic nations, too, are not exempt from this challenge although their governmental structure does, in advance, curb and moderate the more substantial pressures that naturally accumulate under authoritarian regimes that do not permit the public broad range of expression. Authoritarian states can always choose a draconian approach like that of Iran, Libya or Syria in order to suppress protests, whether they are aided by social media or not. However, these steps exact a high price, both in terms of the regime's internal legitimacy and its international relations, with all of the attendant political and economic consequences that they might entail. It seems that, at least those countries where the revolutions succeeded in toppling their geriatric regimes, any leadership that might be established will probably need to take into account the new "rules of the game" introduced by the Arab Spring. These rules redefine the balance of power between the government and the public, for whom the "weapon" of being able to organize effective protests in short order, seems likely to remain relevant farther into the future.

The social media's role in the Arab Spring should be understood in its broader context, namely, as one expression of larger, global and multidisciplinary changes created by this new media. Its radical impact is evident in a wide range of areas, 


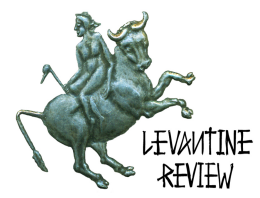

political and non-political, ranging from the news business to cybernetic social arenas in which many young people are intensively active. Indeed, the significant involvement of social media in the Arab Spring provides additional proof of the impact of globalization. However, the patterns of change in the region will not necessarily copy parallel developments in the West or elsewhere. Acquiring skill in the instrumental use of modern technology does not guarantee the adoption of accompanying Western values. It does not require abandoning cultural values or destroying traditional social structures. Rather, the process of change might be a gradual one that creates unique social and political spheres that express local conditions as well as shared global characteristics.

* Harel Chorev is a lecturer and researcher in the department of Middle Eastern and African History at Tel Aviv University. His fields of interest are Network Analysis and its implementation in Middle Eastern studies, history of the Family, Palestinian history, Lebanese history and Internet in the Middle East. 